\title{
(6) OPEN ACCESS \\ Oral health of elite athletes and association with performance: a systematic review
}

\author{
P Ashley, ${ }_{1}^{1}$ A Di lorio, ${ }^{2}$ E Cole, ${ }^{3}$ A Tanday, ${ }^{3}$ I Needleman ${ }^{2}$
}

\begin{abstract}
- Additional material is published online only. To view please visit the journal online (http://dx.doi.org/10.1136/ bjsports-2014-093617).

${ }^{1}$ Unit of Paediatric Dentistry, UCL Eastman Dental Institute, London, UK

${ }^{2}$ UCL Eastman Dental Institute London, UK

${ }^{3}$ Eastman Dental Hospital, UCLH, London, UK
\end{abstract}

\section{Correspondence to} Dr P Ashley, Unit of Paediatric Dentistry, UCL Eastman Dental Institute, 256 Gray's Inn Rd, London WC1X 8LD, UK; p.ashley@ucl.ac.uk

Accepted 26 October 2014 Published Online First 11 November 2014

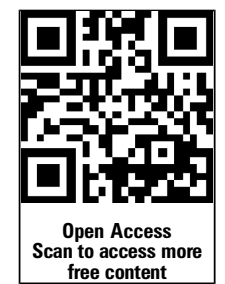

CrossMark

To cite: Ashley $\mathrm{P}, \mathrm{D}$ lorio $\mathrm{A}$, Cole $\mathrm{E}$, et al. Br J Sports Med 2015;49:14-19.

\begin{abstract}
Background We aimed to systematically review the epidemiology of oral disease and trauma in the elite athlete population and to investigate the impact of oral health on sporting performance.

Methods Authors searched Ovid MEDLINE (1950 to October 2013), Ovid EMBASE (1980 to October 2013), EBSCO SPORTDiscus (up to October 2013) and OpenGrey (http://www.opengrey.eu). No date or language restrictions were applied. Papers were included if they evaluated the oral health of professional athletes. The methodological quality of papers was evaluated using a modification of the Newcastle-Ottawa scale.
\end{abstract}

Results The literature search led to 9858 potentially relevant citations. Following a set of predefined exclusion criteria, 34 studies remained. Twenty-six studies reported on dental trauma, which ranged in prevalence from $14 \%$ to $47 \%$ varying by sport and country. Sixteen studies considered the oral health of athletes and reported high prevalence of oral diseases: dental caries $15-75 \%$, dental erosion $36-85 \%$, periodontal disease $15 \%$. In four studies, a range between $5 \%$ and $18 \%$ of athletes reported negative impact of oral health or trauma on performance. The methodological quality of included studies was generally low.

Conclusions Within the limits of the review, oral health of athletes is poor. We hypothesise that poor oral health associates with self-reported performance; however, this needs to be tested. Further studies on representative samples of athletes are needed to assess the size of the problem of poor oral health as well as to investigate the possible impact on performance using objective measures of performance.

\section{INTRODUCTION}

Oral health is an important element of overall health, well-being and quality of life. The nexus between sport and oral health has largely been investigated through studies focused on the risk of trauma to oral health. However, athletes may have poor oral health including high levels of dental caries, dental erosion and dental trauma. ${ }^{1}$ Poor oral health can reduce quality of life and induce a systemic inflammatory response. ${ }^{2} 3$ Thus, poor oral health could affect athletic performance. ${ }^{4}$ However, the relationship between oral health and performance is not well understood. Therefore, we aimed to systematically review the evidence to determine the epidemiology of oral disease and trauma in the elite athlete population. We also investigated the impact of oral health on sporting performance.

\section{METHODS}

We conducted a systematic review of the available literature to answer the focused question-What is the oral health of athletes and what is the effect of oral health on athletic training and performance?

The following eligibility criteria were used when considering studies for this review:

- All types of study design;

- Elite/professional athletes;

- Any outcome measure of oral health (eg, Decayed Missing Filled Teeth (DMFT)) or any impact of oral health on athletic performance.

Studies assessing the impact of interventions on oral health were not included as the aim of this study was to review the epidemiology of oral conditions.

\section{Search methods for identification of studies} Electronic searches

We searched Ovid MEDLINE (1950 to October 2013), Ovid EMBASE (1980 to October 2013), EBSCO SPORTDiscus (up to October 2013) and OpenGrey (http://www.opengrey.eu). No date or language restrictions were applied. We anticipated a wide range of terms for possibly relevant studies and therefore designed a sensitive electronic search strategy.

In MEDLINE we developed a subject-specific search strategy using the following $\mathrm{MeSH}$ terms: Dentistry, Oral Health, Stomatognathic Diseases, Dental Auxiliaries, Dental Staff, Dentists, Halitosis, Stomatognathic System, Facial Pain, Dental Health Education, Maxillofacial Injuries, Jaw Fractures, Mandibular Injuries, Sports, Physical Fitness, Exercise, Physical Exertion, Athletic Injuries, Sports Medicine, Athletes. This search strategy was adapted for EMBASE and SPORTDiscus. The following search filters were used to identify randomised controlled trials and observational studies: Cochrane Highly Sensitive Search Strategy for identifying randomised trials in MEDLINE: sensitivity-maximising version (2008 revision); SIGN Observational Studies search filter (MEDLINE); SIGN Randomised Controlled Trials search filter (EMBASE); SIGN Observational Studies search filter (EMBASE). ${ }^{5}$

\section{Searching other resources}

We checked the reference lists of included studies.

\section{Data extraction}

Papers potentially suitable for inclusion were selected from the title and abstracts by one of the authors (PA). Data extraction was then carried out by two of the authors in duplicate and independently (EC and AT). Disagreements were resolved by discussion. Data extraction was carried out with a specially developed form (piloted before use). Data extracted related to the type of study, methodological quality, type of sport and oral health and its impact or association with performance. 
Since the research question was answerable by observational studies, we assessed their methodological quality using a modification of the Newcastle-Ottawa scale for cross-sectional or cohort studies. ${ }^{6}$ Papers were assessed according to the type of study design, whether they had a clearly stated study objective, if a control population was used and whether oral health was assessed using examination by a dental health professional or athlete self-report. In view of the anticipated heterogeneity of studies we did not plan to conduct meta-analysis of the data.

\section{RESULTS}

We carried out the searches in October 2013. The adopted search strategies led to 9858 potentially relevant citations. After examination of the title and/or abstract, 9723 of these studies were excluded because they did not meet the inclusion criteria. Of the 135 studies retrieved for full text screening, we excluded a further 101 as they were not relevant to the research question. Thirty-four studies were finally eligible for the review. ${ }^{1}$ 7-39

\section{Characteristics of included studies}

The greatest proportion of studies was from Europe (38\%) with the remainder distributed across the globe. Publication dates ranged from $1969^{19}$ to $2013^{1}$ (table 1 ). A wide range of sports were evaluated, with Olympic events well represented. The average number of participants per study was 324 with a minimum of $18^{15}$ and a maximum of $2739 .^{9}$ These studies are summarised in online supplementary table S1.

\section{Methodological quality}

In general, methodological quality was low with all the studies being at risk of bias (online supplementary table S2). Three of the studies attempted to relate the athlete data to a comparison population. ${ }^{17} 2529$ Examiner training or calibration was limited or not reported. Convenience sampling (as opposed to complete or random) was commonly used, particularly when studies were carried out as part of larger sporting events.

For the purposes of this review, studies were divided into two different categories:

1. Epidemiological survey-These were studies where athletes were examined to determine the prevalence of a specific condition (34\% of all studies). They were characterised by either having an independent dental examiner screening a population for a particular disease or by relying on selfreported data with no validation by oral examination. Sampling was either by random selection or a convenience sampling approach.

2. Injury or treatment audit-These were studies where prevalence or incidence of a specific condition was determined by presentation at a clinic for treatment of that condition or by using retrospective cohort data from treatment records or databases (32\% of all studies).

\section{Epidemiology of oral diseases and trauma}

Oral diseases or conditions in the context of this review were divided into dental trauma, caries, periodontal disease, erosion/ wear and pericoronitis/impacted third molars. These are summarised below. We judged that data from epidemiological studies were likely to be less susceptible to bias than data from injury/treatment audits and that self-reported oral health data were subject to the highest bias. Therefore data for the different oral conditions are presented separately in each of these three categories.
Dental trauma

\section{Study characteristics}

Trauma was reported in the majority of studies $(n=28$ papers, $82 \%$ of all included studies) and as primary outcome in 19 studies (56\%). Basketball, ice hockey and rugby were the most frequently investigated sports (table 1). The types of trauma evaluated also varied greatly with studies evaluating some or all of the following: maxillary/mandibular fractures, tooth fractures/avulsions, oral lacerations, facial lacerations and contusions. These were often grouped together so it was not always possible to separate out data for tooth injuries from other injuries of the face or head.

Data were reported either as a proportion of all injuries, of all participants or of all athlete exposures. Sampling frames were either the incidence of trauma recorded over a set period of time or over the entire career of an athlete (usually retrospective) or prevalence of trauma as assessed at the examination. Data on incidence was difficult to summarise, as the total time period was often not reported. We have assumed that data were reported per patient rather than per tooth, although this was not always clear.

Injury audits were the most common design $(n=13,38 \%)$. With the exception of Dorney, ${ }^{17} \mathrm{Ma},{ }^{25}$ and Persson and Kiliaridis, ${ }^{29}$ control groups were not used for comparison of trauma incidence.

\section{Outcome data}

We could not summarise the range of incidence as sampling frames were poorly reported (table 1). The prevalence of sport-related dental trauma varied greatly between studies (range 14-57\%) and between the types of sport investigated. Studies where comparison groups were reported showed a higher prevalence of trauma in the professional/elite group compared with the controls: professional basketball players $80.6 \%$ versus semiprofessional players $47.7 \%,{ }^{25}$ wrestlers $57.7 \%$ versus controls (non-athletes) $26.9 \% .{ }^{29}$ Data on mouthguard use (or other facial protection) were reported in $43 \%$ of studies. When reported, it was unclear whether mouthguards were used before or after a dental injury was experienced. Uptake of mouthguards was variable (0-84.6\%) with the highest uptake rates seen in rugby.

Despite these limitations, it appears that approximately half of athletes in certain sports when asked about their career to date reported an experience of mouth or face injury. However, in one study, although $48 \%$ had experienced dental trauma, only $26 \%$ of the entire sample had experienced dental trauma related to their sport.

\section{Caries}

Caries was evaluated in 15 studies (44\%) and recorded as DMFT or Decayed Missing Filled Surfaces (DMFS), treatment provided or proportions of athletes with caries. Most of the studies were epidemiological surveys $(n=11,73 \%)$ with the remainder treatment audits (table 2). There was a significant burden of disease in the athlete population. Where caries was recorded as a proportion, it ranged from $15 \%$ to $75 \%$ of all athletes (excluding fillings, extractions, etc). Only one of the studies attempted to compare the athletes with a control population $^{29}$ (age-matched non-athlete control). Caries levels in wrestlers and the control population were similarly high. However, the control group was selected from 'regular patients' and may not represent a normal population. None of the other studies compared data with either controls or population norms. Owing to this lack of comparative data, it is difficult to make 
Table 1 Maxillofacial trauma in sport for different study types

\begin{tabular}{|c|c|c|c|c|c|}
\hline Sport & Study type & Author/number of participants & Sport-related maxillofacial/dental injury & Sampling frame & Mouthguard use \\
\hline \multirow[t]{2}{*}{ Basketball } & Injury or treatment audit & Deitch et $a l^{16} \mathrm{n}=1145$ & $\begin{array}{l}1.2 \% \text { National Basketball Association, } 1 \% \\
\text { Womens } \\
\text { National Basketball Association }\end{array}$ & 1996-2002 & Not reported \\
\hline & Epidemiological survey (self-reporting) & $\begin{array}{l}\text { Azodo et } a l^{8} n=156 \\
\text { Frontera et }\left.a\right|^{20} n=388 \\
M a^{25} n=77\end{array}$ & $\begin{array}{l}69.2 \% \\
50 \% \\
42 \%\end{array}$ & $\begin{array}{l}\text { Previous year (unclear) } \\
\text { Any sport-related trauma to date } \\
\text { Any sport-related trauma to date }\end{array}$ & $\begin{array}{l}\text { Not reported } \\
1 \% \\
\text { Not reported }\end{array}$ \\
\hline Field hockey & Epidemiological survey (self-reporting) & Bolhuis et $a l^{10} \mathrm{n}=279$ & $62 \%$ & Self-report, ever been injured & $33 \%$ \\
\hline \multirow[t]{2}{*}{ Football } & $\begin{array}{l}\text { Epidemiological survey (oral } \\
\text { examination) }\end{array}$ & Gay-Escoda ${ }^{21} n=30$ & $23 \%$ & $2003-2006$ & $0 \%$ \\
\hline & - & Randell $^{31} \mathrm{n}=34$ & $26.5 \%$ & 1983 & Not reported \\
\hline Karate & Injury or treatment audit & McLatchie $^{26} \mathrm{n}=295$ & $2 \%$ & 1975 & Not reported \\
\hline \multirow[t]{4}{*}{ Ice hockey } & Epidemiological survey(oral examination) & Stuart et $a l^{36} \mathrm{n}=282$ & $14.2 \%$ all head and neck injuries & One season & Unclear \\
\hline & Injury or treatment audit & Kuzuhara et $a l^{23} \mathrm{n}=94$ & $13 \%$ of all injuries reported & $2002-2005$ & Not reported \\
\hline & & $\begin{array}{l}\text { Pettersson and Lorentzon }{ }^{30} \\
\mathrm{n}=376\end{array}$ & $2.2 \%$ all traumatic injuries & 1986-1990 & Not reported \\
\hline & & Sane et $a l^{32}$ number unclear & $11.5 \%$ all traumatic injuries & Unclear & Not reported \\
\hline $\begin{array}{l}\text { Multisports } \\
\text { games }\end{array}$ & $\begin{array}{l}\text { Epidemiological survey (oral } \\
\text { examination) }\end{array}$ & Andrade et $a l^{7} \mathrm{n}=120$ & $26.3 \%$ & Any sport-related trauma to date & Not reported \\
\hline \multirow[t]{8}{*}{ Rugby } & Injury or treatment audit & $\begin{array}{l}\text { Needleman et } a l^{1} n=278 \\
\text { Sharma et }\left.a\right|^{33} n=342 \\
\text { Soler Badia et }\left.a\right|^{34} n=266 \\
\text { Vougiouklakis et }\left.a\right|^{38} n=658\end{array}$ & $\begin{array}{l}17.6 \% \text { athletes attending the clinic } \\
0.6 \% \text { athletes attending the clinic } \\
1 \% \text { athletes attending the clinic } \\
3 \% \text { athletes attending the clinic }\end{array}$ & $\begin{array}{l}2012 \text { Olympic games } \\
2010 \text { Commonwealth games } \\
1992 \text { Olympic Games } \\
2004 \text { Olympic and Paralympic } \\
\text { games }\end{array}$ & $\begin{array}{l}32.7 \% \text { all athletes presenting with trauma } \\
\text { Not reported } \\
\text { Not reported } \\
\text { Not reported }\end{array}$ \\
\hline & & Yang et $a \beta^{\beta 9} \mathrm{n}=795$ & $0.4 \%$ athletes attending the clinic & 2008 Olympic games & Not reported \\
\hline & Epidemiological survey (self-reporting) & Needleman et al ${ }^{1} n=278$ & $30 \%$ & Self-report, ever been injured & $98 \%$ all athletes \\
\hline & Injury or treatment audit & Dorney $^{17} n=25$ & $52 \%$ & Unclear & $\begin{array}{l}62 \% \text { of all players who experienced } \\
\text { trauma }\end{array}$ \\
\hline & Epidemiological survey (self-reporting) & $\begin{array}{l}\text { Chapman and Nasser }{ }^{12} \mathrm{n}=102 \\
\text { Davies et } a l^{13} n=281\end{array}$ & $\begin{array}{l}26.9-42.3 \% \\
45 \%\end{array}$ & $\begin{array}{l}\text { Any sport-related trauma to date } \\
\text { Any sport-related trauma to date }\end{array}$ & $\begin{array}{l}79.2-84.6 \% \\
24 \%\end{array}$ \\
\hline & & Kay et $a l^{22} \mathrm{n}=63$ & $54 \%$ & Any sport-related trauma to date & $63 \%$ \\
\hline & & Muller-Bolla et $a^{28} n=1140$ & $29.6 \%$ & Any sport-related trauma to date & $64 \%$ \\
\hline & & Stokes and Chapman ${ }^{35} \mathrm{n}=21$ & $47.6 \%$ & Any sport-related trauma to date & 85.7 \\
\hline Taekwondo & Injury or treatment audit & Beis et $a l^{9} \mathrm{n}=2739$ & 3 per 1000 athlete exposures (oral and facial) & $1994 / 1995$ & Not reported \\
\hline Wrestling & $\begin{array}{l}\text { Epidemiological survey (oral } \\
\text { examination) }\end{array}$ & Persson and Kiliaridis ${ }^{29} n=51$ & $\begin{array}{l}57.7 \% \text { wrestlers } \\
26.9 \% \text { age-matched controls (non-athlete) }\end{array}$ & Unclear & Not reported \\
\hline Wrestling & Injury or treatment audit & Faye et $a l^{18} n=125$ & $63 \%$ & Any sport-related trauma to date & $0 \%$ \\
\hline
\end{tabular}

Data is reported as proportion of athletes experiencing trauma unless described otherwise in the text. Data from audits and self-reported surveys describes incidence; data from epidemiological surveys with oral examination describes prevalence. 
Table 2 Caries, periodontal disease, dental erosion/tooth wear, pericoronitis and TMJ disease

\begin{tabular}{|c|c|c|c|c|c|c|c|}
\hline Sport & Study type & $\begin{array}{l}\text { Author/number of } \\
\text { participants }\end{array}$ & Caries & Periodontal disease & $\begin{array}{l}\text { Dental erosion/ } \\
\text { tooth wear }\end{array}$ & $\begin{array}{l}\text { Pericoronitis/impacted third } \\
\text { molar }\end{array}$ & TMJ disease \\
\hline Biathlon & $\begin{array}{l}\text { Epidemiological survey (oral } \\
\text { examination) }\end{array}$ & Lundell ${ }^{24} \mathrm{n}=31$ & $22 \%$ with caries & $\begin{array}{l}\text { Periodontal disease requiring } \\
\text { care }=6 \%\end{array}$ & Not reported & $\begin{array}{l}39 \% \text { required wisdom tooth } \\
\text { removal }\end{array}$ & $6 \%$ TMJ disorder \\
\hline Cycling & $\begin{array}{l}\text { Epidemiological survey (oral } \\
\text { examination) }\end{array}$ & Milosevic et $\left.a\right|^{27} \mathrm{n}=20$ & Mean DMFS=11.6 (SD 8.4) & Not reported & $\begin{array}{l}85 \% \text { athletes with } \\
\text { wear into dentine }\end{array}$ & Not reported & Not reported \\
\hline \multirow[t]{3}{*}{ Football } & $\begin{array}{l}\text { Epidemiological survey (oral } \\
\text { examination) }\end{array}$ & $\begin{array}{l}\text { de Sant'Anna et } a l^{15} \\
\mathrm{n}=18\end{array}$ & Mean $\mathrm{DMFT}=8$ & Not reported & Not reported & Not reported & Not reported \\
\hline & & $\begin{array}{l}\text { Gay-Escoda et } a^{21} \\
\mathrm{n}=30\end{array}$ & $\begin{array}{l}\text { Mean DMFT=5.7 } \\
\text { (SD 4.1) }\end{array}$ & $\begin{array}{l}\text { Plaque score }=2.3 \text { (SD 1.1) } \\
\text { Gingival score }=1.1 \text { (SD 0.8) } \\
\text { Pocket depth=1.9 mm (SD } \\
0.3 \text { ) }\end{array}$ & Not reported & Not reported & $\begin{array}{l}6.7 \% \text { with deviation on opening, } \\
\text { clicking in } 16.7 \%\end{array}$ \\
\hline & & Randel $^{31} \mathrm{n}=34$ & $\begin{array}{l}21 \% \text { with untreated caries/pulp } \\
\text { exposures }\end{array}$ & $\begin{array}{l}3 \% \text { advanced periodontal } \\
\text { disease }\end{array}$ & Not reported & $\begin{array}{l}32 \% \text { with impacted third } \\
\text { molars }\end{array}$ & Not reported \\
\hline \multirow[t]{7}{*}{$\begin{array}{l}\text { Olympic sports/ } \\
\text { Mixed sports }\end{array}$} & $\begin{array}{l}\text { Epidemiological survey (oral } \\
\text { examination) }\end{array}$ & de Cardenas $^{14}$ n=209 & $75.12 \%$ with caries & Not reported & Not reported & Not reported & Not reported \\
\hline & Injury or treatment audit & Forrest $^{19} \mathrm{n}=350$ & Mean DMFT ranged from 2.8 to 16.8 & $\begin{array}{l}\text { Mean periodontal score } \\
\text { ranged from } 0.6 \text { to } 2.2\end{array}$ & Not reported & $\begin{array}{l}4 \% \text { all emergency visits were } \\
\text { for pericoronitis }\end{array}$ & Not reported \\
\hline & & $\begin{array}{l}\text { Needleman et al }{ }^{1} \\
\mathrm{n}=278\end{array}$ & $41 \%$ with caries into dentine & $\begin{array}{l}76 \% \text { BPE } 1 \text { or } 2 \\
15 \% \text { BPE } 3 \text { or } 4\end{array}$ & $\begin{array}{l}\text { Present in } 44.6 \% \text { of } \\
\text { athletes }\end{array}$ & $9.9 \%$ with pericoronitis & Not reported \\
\hline & & Szekely $^{37} n=197$ & Caries was $23 \%$ of all diseases & Not reported & Not reported & Not reported & Not reported \\
\hline & & Sharma et $a l^{33} n=342$ & $\begin{array}{l}\text { Fillings/temporary fillings } 20 \%, \\
\text { endodontics } 3 \% \text {, extractions } 1 \%\end{array}$ & Not reported & Not reported & Not reported & Not reported \\
\hline & & $\begin{array}{l}\text { Soler Badia et al } \\
\mathrm{n}=266\end{array}$ & $\begin{array}{l}\text { Broken/lost filling } 20 \% \text {, pulpitis } 18 \% \text {, } \\
\text { caries } 15.8 \% \text { (athletes only) }\end{array}$ & Not reported & Not reported & $\begin{array}{l}4.6 \% \text { with pericoronitis or } \\
\text { impacted wisdom teeth }\end{array}$ & Not reported \\
\hline & & $\begin{array}{l}\text { Vougiouklakis et } a^{\beta 8} \\
\mathrm{n}=658\end{array}$ & $\begin{array}{l}\text { Fillings/temporary fillings } 50 \% \text {, } \\
\text { endodontics } 13 \% \text {, extractions } 16 \% \\
\text { Data from athletes and non-athletes }\end{array}$ & Not reported & Not reported & Not reported & Not reported \\
\hline \multirow[t]{2}{*}{ Swimming } & $\begin{array}{l}\text { Epidemiological survey (oral } \\
\text { examination) }\end{array}$ & Yang et $a l^{39} \mathrm{n}=795$ & $\begin{array}{l}\text { Fillings/temporary fillings } 29 \% \text {, } \\
\text { endodontics } 16 \% \text {, extractions } 3 \% \\
\text { Data from athletes and non-athletes }\end{array}$ & Periodontal treatment $4 \%$, & Not reported & Not reported & $\begin{array}{l}0.15 \% \text { of all visits to the Olympic } \\
\text { dental clinic }\end{array}$ \\
\hline & & $\begin{array}{l}\text { Milosevic et al }{ }^{27} \\
\mathrm{n}=205\end{array}$ & DMFS=6.2 (SD 8.6) & Not reported & $\begin{array}{l}36 \% \text { wear into } \\
\text { dentine }\end{array}$ & Not reported & Not reported \\
\hline Triathlon & $\begin{array}{l}\text { Epidemiological survey (oral } \\
\text { examination) }\end{array}$ & Bryant et al ${ }^{11} \mathrm{n}=31$ & $\begin{array}{l}\text { DMFT } 0-4 \text { in } 6 \text { cases, } 9 \text { in } 2 \text { cases } \\
\text { Patients self-reported as moderate to } \\
\text { high caries risk }\end{array}$ & 'Good' & Not reported & Not reported & Not reported \\
\hline Wrestling & $\begin{array}{l}\text { Epidemiological survey (oral } \\
\text { examination) }\end{array}$ & $\begin{array}{l}\text { Persson and } \text { Kiliaridis }^{29} \\
\mathrm{n}=51\end{array}$ & $\begin{array}{l}\text { DFT } 9.4 \text { (SD 3.9) wrestlers } \\
\text { DFT } 8.2 \text { (SD 5.5) control population }\end{array}$ & Not reported & Not reported & Not reported & $\begin{array}{l}\text { No difference between test wrestling } \\
\text { and control }(<0.05) \text { ( } 1 \text { individual per } \\
\text { group with TMJ tenderness) }\end{array}$ \\
\hline
\end{tabular}

BPE, basic periodontal examination; DFT, decayed and filled teeth; DMF, Decayed Missing Filled; DMFS, DMF surfaces; DMFT, DMF Teeth; TMJ, temporomandibular joint. 
any statements regarding the oral health of elite athletes relative to a non-athlete population.

\section{Periodontal disease}

Periodontal disease was evaluated in seven (21\%) of the studies by a diverse group of measures including the Basic Periodontal Examination, plaque, gingivitis and an overall qualitative assessment (table 2). The prevalence of irreversible moderate to severe periodontal disease was reported to be up to $15 \%$ with gingivitis up to $76 \% .{ }^{1}$ Data from control groups, or population norms, were not presented.

\section{Dental erosion/tooth wear}

Dental erosion/tooth wear was reported in four studies (12\%) with no data from control populations. Proportions of athletes with wear into dentine were high, ranging from 36\% to $85 \%$ (table 2), with only one study recording no wear. ${ }^{11}$

\section{Pericoronitis/impacted third molar}

Five studies reported on pericoronitis or impacted third molars. In all of the studies at least some athletes were either exhibiting symptoms related to pericoronitis or were judged to require removal of one or more wisdom teeth (range, 4.6-39\%; table 2).

\section{Other oral health problems}

Temporomandibular joint dysfunction (TMD) was reported by four studies, ${ }^{21} 242939$ with a low reported prevalence overall (table 2).

\section{Impact of oral health on well-being, training and performance}

Four studies reported the impact of oral health on performance using athlete-reported outcome measures with two studies focusing on Olympic athletes, ${ }^{1}{ }^{34}$ one on basketball players ${ }^{20}$ and one on footballers. ${ }^{21}$ Impact was not the primary outcome for any of these studies and the validity of most tools to assess impact is unknown. However, all studies reported an impact of oral health on performance. In one of these, ${ }^{34}$ data from athletes and non-athletes were combined (only 54\% of respondents were athletes). Eight per cent of those surveyed thought that oral problems had disturbed their training and 5\% thought it had affected their sporting performance. A second study was a cross-sectional, prospective evaluation of the oral health of athletes competing in the 2012 London Olympics. ${ }^{1}$ Athletes underwent a full oral examination, and the impact of oral health on performance was assessed using a modification of the shortened global evaluation of impact of oral health on quality of life. ${ }^{40}$ Responses were scored on a five-point scale. More than $40 \%$ of athletes were bothered by their oral health with $28 \%$ reporting an impact on quality of life and $18 \%$ on training and performance. Exploratory analysis suggested that impact was significantly associated with levels of caries whether analysed by median number of carious lesions per athlete or number of athletes with caries $(\mathrm{p}<0.001)$.

A relationship between oral health (dental plaque index) and performance (number of intrinsic injuries, ie, muscle, ligament/ tendon or bone) was also found in a study at Barcelona football club. ${ }^{21}$ However, the potential significance of this, or mechanism for the relationship, was not explored.

Finally, Brazilian basketball players reported in a questionnaire-based study ${ }^{20}$ increased insecurity about playing after match-related orofacial trauma (33\% of those sampled).
Sixty-six per cent reported that oral problems could 'diminish their strength'.

\section{DISCUSSION \\ Key findings}

Our primary outcome is that in contrast to the common perception that athletes are healthy 'all over', the oral health of sampled athletes is poor. Caries occurred in up to $75 \%$ of athletes surveyed; athletes experienced other oral problems such as periodontal disease, dental erosion and dental trauma. Data from studies examining oral health and performance suggested that poor oral health had a negative effect on athlete's selfreported training and performance.

\section{Strength and limitations of included evidence}

There were many challenges to drawing robust conclusions from the available literature. For instance, while we retrieved 34 eligible studies, most were focused on dental trauma with less than half of the studies reporting more broadly on oral health. A low level of methodological quality of many of the studies further restricted our ability to draw conclusions. In addition, data on the impact of oral health on well-being and performance was extracted mostly from one study and should be interpreted with caution.

\section{Risk of bias}

In general all studies assessed in this review were subject to one or more forms of methodological bias (online supplementary table S2). These included lack of reported training or calibration of outcome assessors and use of convenience samples. Therefore, it is not clear whether the data are truly representative of athletes. A lack of data for comparison groups within studies-that is, matched other than elite sport participation-is another common issue. Without an understanding of the control group, it is more difficult to determine the portion of risk of disease attributable in some way to elite sport and also to compare differences between sports and locations.

\section{Outcome assessment}

The outcome measures varied between studies. For example, caries-related outcomes included DMFT, untreated decay, decayed surfaces and filled teeth. This lack of consistency between trials made comparison of results difficult. Agreement on a common data set would facilitate comparison between studies and changes over time. Most studies did not report on examiner calibration or repeatability training resulting in greater uncertainty around the accuracy and validity of the data. The large number of studies (34\%) relying on non-validated selfreporting of health data was also problematic.

Athlete-reported impacts on performance, like other patientreported outcome measures, could be an important approach for capturing outcomes from athletes. ${ }^{41}$ Further research of such outcomes is potentially a promising approach to understanding the athlete perspective on injury and illness. In addition, outcome measures that quantify effects on performance could also be assessed including time lost to training and severity of impact. ${ }^{42}$

\section{Significance of findings and possible mechanisms}

Data from this review suggest that athletes have poor oral health. This is a striking finding considering that the most prevalent oral health conditions in this review are preventable, that is, dental caries, erosion and periodontal diseases and also that these individuals have otherwise excellent general health. 
According to the Olympic Charter, the International Olympic Committee and the International Sport Federations have an obligation 'to encourage and support measures protecting the health of athletes'. ${ }^{43}$ Oral health is an area that has perhaps been overlooked previously when considering athletes' health.

The possible negative impact from poor oral health on elite performance warrants further investigation, although this is not a new finding. ${ }^{19}$ It is highly plausible that oral health could affect performance in view of the well-recognised effects of oral health on health-related quality of life. ${ }^{40}$ Mechanisms could include pain, effects on eating, psychological impacts and raised systemic inflammatory burden, and will need detailed investigation. Reduced performance due to poor oral health is unacceptable as well as preventable. The effect of poor oral health on these athletes in later life is also unknown but is likely to cause considerable impacts, including a high treatment need, tooth loss, reduced oral function and psychological effects. ${ }^{40}$

Possible sport-related causes of poor oral health include frequent dietary intake of carbohydrates, ${ }^{11}$ physiological changes such as decreased salivary flow and drying of the mouth during exercise $^{44}$ and exercise-induced immune suppression. ${ }^{45}$ Demanding training regimes might make it difficult to access preventive care. Other challenges to oral health might include low levels of oral health literacy, beliefs of the athlete and their support network, and a lack of prioritisation of oral health within sport. There is a clear need to investigate these barriers and facilitators.

Interestingly, poor oral health did not seem to be related to availability (or lack thereof) of highly organised dental care. Many of the athletes in this survey were from countries with well-developed healthcare systems; this suggests that current strategies for oral care of elite athletes are not effective in maintaining oral health. Further information on the general oral health of the non-athlete population is needed for comparison.

\section{Potential biases in this review}

We made the decision to only include elite athletes as we felt this group warranted specific investigation. This focus resulted in several studies being excluded because they investigated non-elite sport including recreational athletes, schoolchildren and university-level athletes. Therefore, the findings cannot be extrapolated to other types of sport participants. Otherwise, we attempted to minimise bias in the review by developing the protocol a priori and employing duplicate data extraction. Eligibility assessment was carried out by only one researcher, which might have introduced bias in study selection.

\section{Future research}

In order to determine the true extent and severity of oral diseases in athletes across a wide range of sports and their impact on performance, epidemiological studies on representative samples are needed, ${ }^{42}$ employing trained examiners and validated outcome measures. Impact on performance should be investigated with the development of validated self-reporting tools $^{1}$ and by using other outcomes such as missed training or competition as a result of oral health-related illness. It is likely that poor oral health will have a negative impact on performance, this assumption should also be tested. Finally, prospective cohort studies are needed to evaluate incidence and risk.

\section{Conclusions}

Within the limits of the review, oral health of athletes is poor. We hypothesise that poor oral health associates with selfreported performance but that needs to be tested. Further studies on representative samples of athletes are needed to assess the size of the problem of poor oral health as well as to investigate the possible impact on performance using objective measures of performance.

\section{What are the new findings}

- The oral health of athletes appears to be poor across a wide range of sports.

- Dental caries and dental erosion affect the majority of sampled athletes with irreversible periodontitis affecting up to $15 \%$ of participants.

- Poor oral health may affect athletic performance.

Contributors EC, AT, PA and IN designed the data collection tools. EC and AT extracted data from the initial data set. Search strategy and literature retrieval was by ADI. Initial analysis and draft was by EC. Final analysis and re-draft were by PA and IN. PA is the guarantor.

\section{Competing interests None.}

Provenance and peer review Not commissioned; externally peer reviewed.

Open Access This is an Open Access article distributed in accordance with the Creative Commons Attribution Non Commercial (CC BY-NC 4.0) license, which permits others to distribute, remix, adapt, build upon this work non-commercially, and license their derivative works on different terms, provided the original work is properly cited and the use is non-commercial. See: http://creativecommons.org/ licenses/by-nc/4.0/

\section{REFERENCES}

1 Needleman I, Ashley P, Petrie A, et al. Oral health and impact on performance of athletes participating in the London 2012 Olympic Games—a cross sectional study. Br J Sports Med 2013;47:1054-8.

2 Locker D. Measuring oral health: a conceptual framework. Community Dent Health 1988;5:5-13.

3 Cullinan MP, Seymour GJ. Periodontal disease and systemic illness: will the evidence ever be enough? Periodontol 2000 2013;62:271-86.

4 Piccininni PM, Fasel R. Sports dentistry and the Olympic Games. J Can Dent Assoc 2005;33:471-83.

5 Scottish Intercollegiate Guidelines Network. Search filters. 2013 [updated 26/04/ 2013 cited 17/02/2013]. http://www.sign.ac.uk/methodology/filters.html

6 The Newcastle-Ottawa Scale (NOS) for assessing the quality of nonrandomised studies in meta-analyses. [cited 03/08/2013]. http://www.ohri.ca/programs/clinical_ epidemiology/oxford.asp

7 Andrade RA, Modesto A, Evans PLS, et al. Prevalence of oral trauma in Para-Pan American games athletes. Dent Traumatol 2013;29:280-4.

8 Azodo CC, Odai CD, Osazuwa-Peters $N$, et al. A survey of orofacial injuries among basketball players. Int Dent J 2011;61:43-6.

9 Beis K, Tsaklis P, Pieter W, et al. Taekwondo competition injuries in Greek young and adult athletes. Eur J Sports Traumatol Relat Res 2001;23:130-6.

10 Bolhuis JA, Leurs JM, Floegel GE. Dental and facial injuries in international field hockey. Br J Sports Med 1987;21:174-7.

11 Bryant S, McLaughlin K, Morgaine K, et al. Elite athletes and oral health. Int J Sports Med 2011;32:720-4.

12 Chapman PJ, Nasser BP. Attitudes to mouthguards and prevalence of orofacial injuries in four teams competing at the second Rugby World Cup. Br J Sports Med 1993;27:197-9.

13 Davies RM, Bradley D, Hale RW, et al. The prevalence of dental injuries in rugby players and their attitude to mouthguards. Br J Sports Med 1977;11:72-4.

14 de Cardenas 0 . Prevalence of teeth problems in elite Cuban athletes as revealed by an orthodontic survey. Deporte Derecho Pueblo 1977;10:44-7.

15 de Sant'Anna GR, Simionato MR, Suzuki ME. Sports dentistry: buccal and salivary profile of a female soccer team. Quintessence Int 2004;35:649-52.

16 Deitch JR, Starkey C, Walters SL, et al. Injury risk in professional basketball players: a comparison of Women's National Basketball Association and National Basketball Association athletes. Am J Sports Med 2006;34:1077-83.

17 Dorney B. Dental injury patterns in football [abstract]. 1999;2:66.

18 Faye $D$, Lo CM, Cisse D, et al. Prevalence of oro-dental injuries in wrestling in Senegal. Odontostomatol Trop 2008;31:29-35.

19 Forrest JO. Dental condition of Olympic Games contestants—a pilot study, 1968. Dent Pract Dent Rec 1969;20:95-101. 
20 Frontera RR, Zanin L, Ambrosano GM, et al. Orofacial trauma in Brazilian basketball players and level of information concerning trauma and mouthguards. Dent Traumatol 2011;27:208-16.

21 Gay-Escoda C, Vieira-Duarte-Pereira DM, Ardevol J, et al. Study of the effect of oral health on physical condition of professional soccer players of the Football Club Barcelona. Med Oral Patol Oral Cir Bucal 2011;16:e436-9.

22 Kay EJ, Kakarla P, Macleod DA, et al. Oro-facial and dental injuries in club rugby union players. Br J Sports Med 1990;24:271-3.

23 Kuzuhara K, Shimamoto $H$, Mase Y. Ice hockey injuries in a Japanese elite team: a 3-year prospective study. J Athl Train 2009;44:208-14.

24 Lundell M. Benefits of oral screening and management of the United States Olympic Biathlon team. Fourth IOC world congress on sport sciences 22-25 October 1997, Principality of Monaco Congress Proceedings. Switzerland: International Olympic Committee, 1997:109.

25 Ma W. Basketball players' experience of dental injury and awareness about mouthguard in China. Dent Traumatol 2008;24:430-4.

26 McLatchie GR. Analysis of karate injuries sustained in 295 contests. Injury 1976;8:132-4.

27 Milosevic A, Kelly MJ, McLean AN. Sports supplement drinks and dental health in competitive swimmers and cyclists. Br Dent J 1997;182:303-8.

28 Muller-Bolla $\mathrm{M}$, Lupi-Pegurier $\mathrm{L}$, Pedeutour $\mathrm{P}$, et al. Orofacial trauma and rugby in France: epidemiological survey. Dent Traumatol 2003;19:183-92.

29 Persson LG, Kiliaridis S. Dental injuries, temporomandibular disorders, and caries in wrestlers. Scand J Dent Res 1994;102:367-71.

30 Pettersson M, Lorentzon R. Ice hockey injuries: a 4-year prospective study of a Swedish elite ice hockey team. Br J Sports Med 1993;27:251-4.

31 Randell S. Dental trauma and disease in 34 professional athletes. Physician Sports Med 1983;11:85-7.

32 Sane JP, Ylipaavalniemi P, Lepanen H. Facial Injuries in Ice Hockey. Int J Sports Biomech 1988;4:395-6.
33 Sharma R, Verma M, Mehrotra G. Dental treatment at the Commonwealth Games, 23 September to 16 October 2010, Delhi, India. Int Dent J 2012;62:144-7.

34 Soler Badia D, Batchelor PA, Sheiham A. The prevalence of oral health problems in participants of the 1992 Olympic Games in Barcelona. Int Dent J 1994;44:44-8.

35 Stokes AM, Chapman PJ. Mouthguards, dental trauma and the 1990 All Blacks. N Z J Sports Med 1991;19:66-7.

36 Stuart MJ, Smith AM, Malo-Ortiguera SA, et al. A comparison of facial protection and the incidence of head, neck, and facial injuries in Junior A hockey players. A function of individual playing time. Am J Sports Med 2002;30:39-44.

37 Szekely G. Clinical check-up of young athletes participating in "Sydney 2000" program. Hung Rev Sports Med 1996;37:5-10.

38 Vougiouklakis G, Tzoutzas J, Farmakis ET, et al. Dental data of the Athens 2004 Olympic and Paralympic Games. Int J Sports Med 2008;29:927-33.

39 Yang X-J, Schamach P, Dai J-P, et al. Dental Service in 2008 Summer Olympic Games. Br J Sports Med 2011:45:270-4.

40 Locker D, Quinonez C. To what extent do oral disorders compromise the quality of life? Community Dent Oral Epidemiol 2011;39:3-11.

41 Davidson M, Keating J. Patient-reported outcome measures (PROMs): how should I interpret reports of measurement properties? A practical guide for clinicians and researchers who are not biostatisticians. Br J Sports Med 2014;48:792-6.

42 Timpka T, Alonso J-M, Jacobsson J, et al. Injury and illness definitions and data collection procedures for use in epidemiological studies in Athletics (track and field) Consensus statement. Br J Sports Med 2014;48:483-90.

43 Mountjoy $M$, Junge $A$. The role of International Sport Federations in the protection of the athlete's health and promotion of sport for health of the general population. Br J Sports Med 2013;47:1023-7.

44 Mulic A, Tveit A, Songe D, et al. Dental erosive wear and salivary flow rate in physically active young adults. BMC Oral Health 2012;12:8.

45 Gleeson M. Immune function in sport and exercise. J App/ Physiol 2007;103:693-9. 